\title{
MENTAL DIAGNOSIS BY THE ASSOCIATION REACTION METHOD.
}

\author{
BY FREDERICK G. HENKE AND MILTON W. EDDY,
}

From the Psychological Laboratory of Northwestern University.

The object of this series of experiments was to verify the validity of the association reaction method in a number of dissimilar experiments conducted with normal subjects. The first two experiments were so planned that they could be carried out before a psychology class within an hour's time. The entire series was so arranged that we gradually restricted any advantage that the operator had and gave the subjects greater opportunity to conceal their relations to the experiments. This was most successfully achieved in the third experiment which we describe. A further object of the first two experiments was to learn what mental diagnosis a class would be led to make from observations during the progress of the experiment, the point of view being to estimate the feasibility of using this method in the presence of a jury. We also wished to discover, if possible, whether knowledge on the part of the subject of the methods used would invalidate the results, as has been asserted.

The instruments used were a chronoscope, measuring time in one-hundredths of a second, a lip-key used by the operator to start a pendulum on the chronoscope at the time of giving the stimulus word, and a mouthpiece into which the subject spoke the associated words, thereby releasing a circuit-breaker, which records on the chronoscope the time elapsing between the giving of the stimulus,word and the reaction word.

\section{EXPERIMENT I.}

Mr. H. and Mr. O. acted as subjects, Mr. H. being a junior and Mr. O. a graduate student. In one corner of a dark-room under a gas-jet stood a child's desk on which were placed Joseph Jastrow's book The Subconscious, a bottle of red ink, pen and paper, and a child's Christmas story book. A hammer was tied to the gas fixture. On a table in another 
corner of the room were an old dusty crushed derby, and a few other things the nature of which will appear in the progress of the experiment. Mr. S. assisted by handing the instructions to $\mathrm{Mr} . \mathrm{H}$. and $\mathrm{Mr}$. O. and seeing that they were fulfilled. One of the men was not to enter the room, the other was to follow out the typewritten directions, which were as follows:

" I. Sit down at the desk. Observe that it is a child's desk. Take up the child's book which is at your right on the desk and read it. Is the poem familiar to you? Are you able to get a mental image of Santa Claus? (See front cover.)"

" 2. Pen, paper and ink are on the desk in front of you. Write the first page of 'The Night Before Christmas,' using the material at hand."

"3. Pick up the book at your left and take note of the following: (1) Its author. (2) The title. Write the name of the author and the title three times with the red ink."

"4. Untie the hammer which is tied to the gas fixture, and knock on the desk with it three times moderately hard. Then await further orders." 1

"5. The building in which you now are is fifty years old. Owing to its age and the fact that it is constructed entirely of wood, there is the greatest danger of fire at any time. In fact the danger is considered so great that the rooms on this fourth story have been abandoned. The building and its contents are heavily insured. The university does not believe it wise to assume any risk. A fire might break out just now. There is a carpenter shop in the basement with wood and oil. What would you do in event of fire? Spend the next few minutes until the clock strikes in devising a plan of escape, if access to the stairs were shut off because of fire. When the bell strikes turn to No. 6."

"6. Back of you there is a door partly open and near you there is a rope. This rope is long enough to reach the fifty feet to the ground. Take up this rope and follow it hand over hand for fifty feet from the door, ${ }^{2}$ then come back the same way and leave the room."

${ }^{1}$ At this juncture the assistant came into the room with an interval clock set to ring in seven minutes and told him to proceed with No. 5 .

1 This rope led fifty feet back into a dark attic. 
"Please do not talk with anybody about the room or what you did in it."

These instructions having been carried out, the assistant brought one of the men into the lecture room before the class and we proceeded to take the associated reactions, the results being as follows :

\section{TABLE I.}

RESUL'TS OF EXPERIMANT I.

\begin{tabular}{|c|c|c|c|c|c|}
\hline \multirow{2}{*}{$\begin{array}{l}\text { No of } \\
\text { Word }\end{array}$} & \multirow{2}{*}{ Stimulus Word. } & \multicolumn{2}{|c|}{ Results for Mr. $\mathbf{H}-$. } & \multicolumn{2}{|c|}{ Results for Mr. $\mathrm{O} \rightarrow$} \\
\hline & & $\begin{array}{l}\text { Association } \\
\text { Word. }\end{array}$ & $\begin{array}{l}\text { Association } \\
\text { Time. }\end{array}$ & $\begin{array}{l}\text { Association } \\
\text { Word. }\end{array}$ & $\begin{array}{l}\text { Association } \\
\text { Time. }\end{array}$ \\
\hline I & Tree. & Tree. & 1.36 & & \\
\hline 2 & Wood. & Log. & 1.50 & Tree. & .87 \\
\hline 3 & Sun. & Boy. & 1.30 & & \\
\hline 4 & Sky. & Air. & 1.82 & Story. & \\
\hline $\begin{array}{l}5 \\
6\end{array}$ & $\begin{array}{l}\text { Father. } \\
\text { To speak. }\end{array}$ & & & $\begin{array}{l}\text { Mother. } \\
\text { Radiator. }\end{array}$ & $\begin{array}{l}1.80 \\
3.25\end{array}$ \\
\hline 7 & Grass. & Lawn. & .90 & Brown. & $\begin{array}{r}3.25 \\
.90\end{array}$ \\
\hline 8 & Sweet. & Sugar. & .97 & Bitter. & 1.30 \\
\hline 9 & Ten. & Twenty. & 1.45 & Men. & 1.67 \\
\hline Io & Blue. & Sky. & 1.20 & Seat. & 1.70 \\
\hline II & Chair. & Desk. & 1.37 & & \\
\hline 12 & Girl. & Boy. & I.IO & Boy. & 1.60 \\
\hline 13 & Supply. & Breakfast. & โ. 47 & Tonight. & 2.40 \\
\hline 14 & To fly. & Bird. & 1.07 & Bird. & 1.17 \\
\hline $15^{*}$ & Christmas. & New Year. & 1.70 & Snow. & I. 67 \\
\hline $16^{*}$ & Interval. & Minute. & 1.67 & One Minute. & 3.25 \\
\hline $17^{*}$ & Skull. & Skeleton. & I. 52 & Neandertal. & 3.70 \\
\hline $18^{*}$ & Sleepy. & Man. & 1.00 & Boy. & 2.40 \\
\hline $19^{*}$ & Joseph. & Boy. & 1.00 & Egypt. & $3 . x 5$ \\
\hline $20^{*}$ & Ink. & Black. & 1.40 & Black. & 1.05 \\
\hline $21^{*}$ & Creature. & Man. & 1.80 & Mouse. & 1.70 \\
\hline $22^{*}$ & Black. & Ink. & .85 & Night. & 2.85 \\
\hline $23^{*}$ & Hammer. & Anvil. & 1.60 & Nail. & 2.75 \\
\hline $24^{*}$ & Old College. & Building. & 1.40 & & \\
\hline $\begin{array}{l}25^{*} \\
26^{*}\end{array}$ & $\begin{array}{l}\text { Fourth Story. } \\
\text { Rope. }\end{array}$ & Building. & 2.65 & $\begin{array}{l}\text { Fifth. } \\
\text { Ground. }\end{array}$ & $\begin{array}{l}2.55 \\
4.00\end{array}$ \\
\hline $27^{*}$ & Fire. & Sherman Ave. & 2.05 & Engine. & 1.80 \\
\hline $28^{*}$ & Danger. & Fire. & 1.80 & Escape. & 3.70 \\
\hline $29^{*}$ & Minutes. & Hours. & $\mathrm{I} .55$ & Fire. & 2.50 \\
\hline $30^{*}$ & Night. & Day. & .90 & Dark. & 3.07 \\
\hline $3 I^{*}$ & Before. & After. & 1.27 & Fisk. & 3.60 \\
\hline $3^{2}$ & To write. & Speak. & & & \\
\hline $33^{*}$ & Conceal. & Plain. & 1.23 & Knowledge. & 2.30 \\
\hline $34^{*}$ & Hat. & Coat. & 1.03 & Black. & 2.40 \\
\hline $35^{*}$ & Dread. & Fear. & 1.55 & & \\
\hline $3^{6^{*}}$ & Conceal. & & & Knowledge. & 2.10 \\
\hline $37^{*}$ & Subconscious. & Conscious. & 1.10 & Stule. & 1.80 \\
\hline $3^{8^{*}}$ & Ink. & Black. & 1.30 & Black. & 1.40 \\
\hline
\end{tabular}

In this table the significant stimulus words are marked with an asterisk, fourteen words having been first introduced to gain 
the normal association time. Mr. H. was first tested and we soon came to the conclusion that he had not been in the room; this was further substantiated when $\mathrm{Mr}$. O. was brought before the class and the length of his association time and the associations to the significant words were noted. At the conclusion of the experiment, before announcing the results to the class, every member was requested to indicate on a slip of paper which one of the two men had been in the room. The entire class, thirty-eight in all, was unanimous in its judgment that Mr. O. had been in the room. Only one of the thirty-eight thought that $\mathrm{Mr}$. H. had also been in the room. We believe that the class drew its conclusions partly from the appearance of emotion in $\mathrm{Mr}$. O., as well as from the manifestly delayed association time, when some of the significant words were given and by the nature of the associations themselves.

Subjoined will be found a table of the quantitative results of the experiments.

TABle II.

QUANTITATIVH RHSULTS OF EXPERIMENT I.

\begin{tabular}{|c|c|c|c|c|}
\hline & \multicolumn{2}{|c|}{ Results for Mr. H-. } & \multicolumn{2}{|c|}{ Results for Mr. O- } \\
\hline & $\begin{array}{l}\text { Irrelevant } \\
\text { Words. }\end{array}$ & $\begin{array}{l}\text { Significant } \\
\text { words. }\end{array}$ & $\begin{array}{l}\text { Irrelevant } \\
\text { words. }\end{array}$ & $\begin{array}{l}\text { Significant } \\
\text { Words. }\end{array}$ \\
\hline $\begin{array}{l}\text { Mean. } \\
\text { Mean Variation. } \\
\text { Difference in Means. }\end{array}$ & $\begin{array}{r}1.25 \\
.29\end{array}$ & $\begin{array}{r}1.62 \\
.26\end{array}$ & $\begin{array}{r}1.77 \\
.56\end{array}$ & $\begin{array}{r}2.54 \\
.63 \\
77 \quad 6\end{array}$ \\
\hline $\begin{array}{l}\text { Extremes }\left\{\begin{array}{l}\text { Lrong. } \\
\text { Short. }\end{array}\right. \\
\text { Maximuin Range. }\end{array}$ & $\begin{array}{r}.85 \\
1.82\end{array}$ & $\begin{array}{r}.90 \\
3.37\end{array}$ & $\begin{array}{r}.87 \\
3.25\end{array}$ & $\begin{array}{r}1.05 \\
4.00\end{array}$ \\
\hline
\end{tabular}

The mean variation of $\mathrm{Mr}$. $\mathrm{H}$. on the irrelevant words was more than on the significant. While in the case of Mr. O. the mean variation for the irrelevant words was less than for the significant words, this being precisely what we expected.

We may sum up the grounds for our conclusion that Mr. O. had been in the room and had attempted to conceal as follows: (I) The association time for Mr. H. was not sufficiently lengthened in the case of the significant words to indicate a voluntary change of association. Mr. O.'s associations were manifestly delayed in the case of some of the significant words. Take, for instance, the two words night and before. These are from 
the poem, 'Twas the Night before Christmas.' Night suggested the word dark, which was long in coming, possibly on account of the highly suggestible words fire, danger and minute just preceding, and when the stimulus word before, which naturally suggested Christmas, was given, Mr. O. changed this to fisk, thereby lengthening the time to 3.60 seconds. The same situation becomes apparent in the case of other significant words which can easily be selected by the reader. (2) Mr. O. gave a number of very significant associations in response to certain stimulus words. This, taken in connection with the highly delayed reactions, forms another basis for our conclusions. The word rope brought up the association ground in 4.00 seconds. An examination of the typewritten directions of this experiment under Number 6 where the sentence occurs, "This rope is long enough to reach 50 feet to the ground," will show just why this word was selected. (3) As we have already shown, Mr. $O$.'s mean variation for the significant words was considerably higher than for the irrelevant words, while the reverse was the case with $\mathrm{Mr}$. $\mathrm{H}$.

\section{EXPERIMENT II.}

In Experiment two, our object was three-fold: First, to discover which one of three subjects had performed a series of acts and was trying to conceal his relation to them ; second, which one had performed the acts, and did not try to conceal; and third, which one knew nothing about them. Mr. J., Mr. S. and Mr. $U$. acted as subjects. We used the same room and the same directions as in Experiment Number I. Mr. W. was assistant and handed the subjects who were entirely ignorant of the nature of the experiment, the typewritten directions. When the subjects had fulfilled their parts, they returned to the lecture room one at a time and their associations were taken as is indicated in the following table:

The reader will readily see that this experiment was much more involved than the previous one, thereby increasing the difficulty of accurate diagnosis. The significant words caused a manifest delay in the association reaction time of $\mathrm{Mr}$. S. This was not the case with $\mathrm{Mr}$. U., while the slight difference 
TABLE III.

RISULTS OF EXPERIMRNT II.

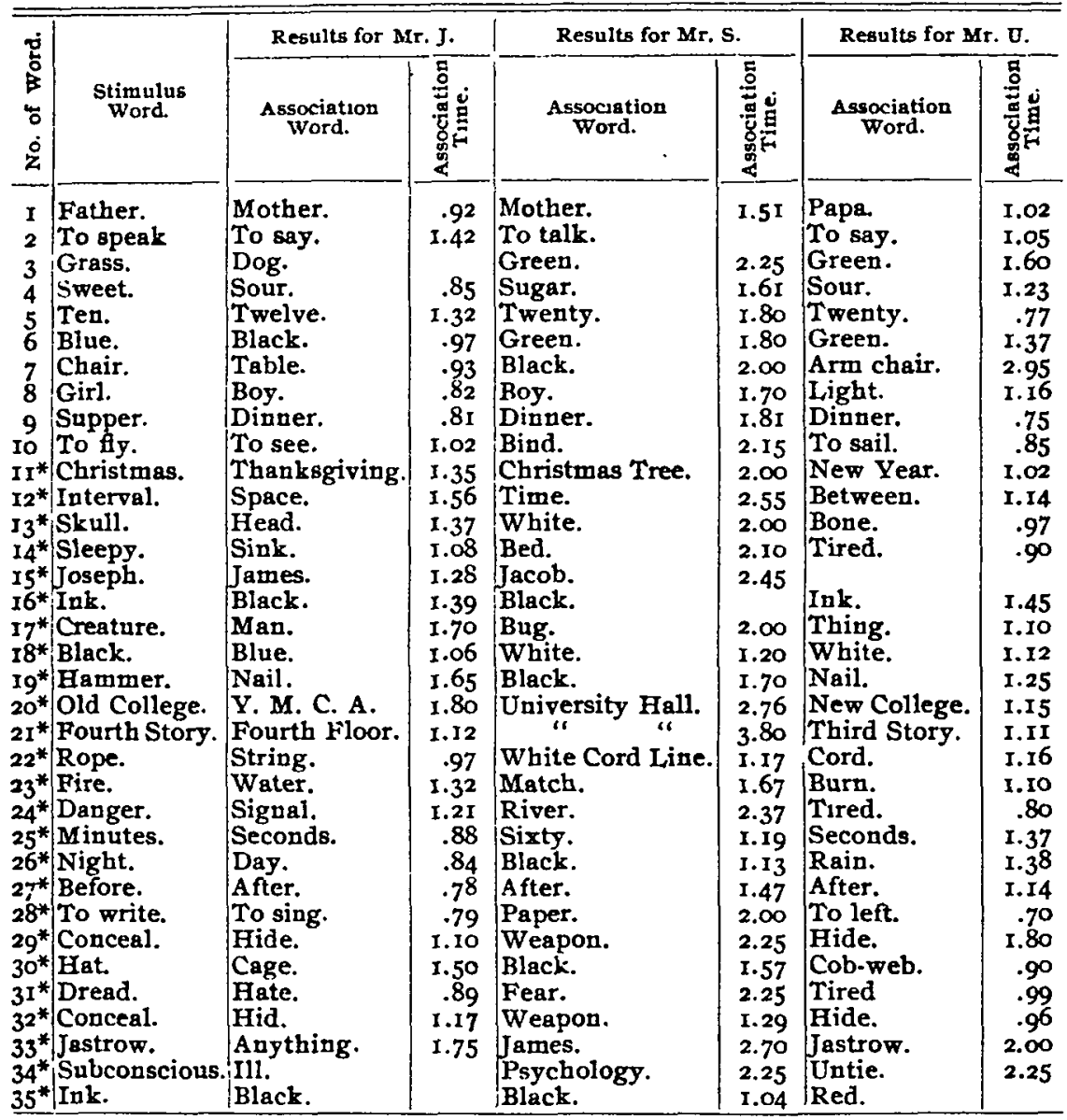

* The significant words are indicated by an asterisk.

in time of $\mathrm{Mr}$. I. could easily be accounted for on account of his unfamiliarity with the strange words. Further the reaction time of Mr. S. is on the whole greater than for Mr. J. or Mr. U., and finally, the variability in the reaction time of the significant words is greater for Mr. S. than for the other two. If we examine the association words of $\mathrm{Mr}$. U. we find two very significant associations. The word hat brought up the word cobzueb. Why? Was it not because the old crushed hat in the 
room was dusty and covered with cobwebs? The word ink brought the response red, probably because the ink on the desk was red. When the word Jastrow was given to $\mathrm{Mr}$. J. he gave the associated word anything, and the tone in which it was said indicated that he was unfamiliar with the word.

Before giving our decision to the class, each member was requested to write on a slip of paper what he believed to be the relation of each of the subjects to the experiment. Eight members were unanimous in their belief that $\mathrm{Mr}$. U. had been in the room and was not trying to conceal it. Six thought Mr. S. had been in the room and was trying to conceal it, and six that Mr. J. had not been in the room.

Our conclusions were as follows: (I) Mr. J, had not been in the room; (2) Mr. S. had been in the room and tried hard to conceal it; and (3) Mr. U. performed the series of acts and did not try to conceal it. We were correct in our judgment. Below are given the quantitative results of Experiment II.; in this the mean variation in the significant words stands out very prominently in the case of Mr. S.

TABLE IV.

QUANTITATIVE RESUT,TS OF EXPERIMENT II.

\begin{tabular}{|c|c|c|c|c|c|c|}
\hline & \multicolumn{2}{|c|}{ Results for Mr J. } & \multicolumn{2}{|c|}{ Results for Mr S. } & \multicolumn{2}{|c|}{ Results for Mr $\mathrm{O}$. } \\
\hline & $\begin{array}{c}\text { Irrelevant } \\
\text { words }\end{array}$ & $\mid \begin{array}{c}\text { Significant } \\
\text { Words. }\end{array}$ & $\begin{array}{l}\text { Irrelevant } \\
\text { Words. }\end{array}$ & $\begin{array}{l}\text { Significant } \\
\text { Words. }\end{array}$ & $\begin{array}{l}\text { Irrelevant } \\
\text { words. }\end{array}$ & $\begin{array}{l}\text { Significant } \\
\text { Words. }\end{array}$ \\
\hline $\begin{array}{l}\text { Mean. } \\
\text { Mean Variation. } \\
\text { Difference in Means. }\end{array}$ & $.16+$ & $\begin{array}{c}1.24 \\
.26+ \\
0.23\end{array}$ & $\begin{array}{l}.85 \\
.19+ \\
+0\end{array}$ & $\int_{0.10}^{1.95} .47+$ & $\begin{array}{r}1.23 \\
.41 \\
+0\end{array}$ & $.02^{.26 t}$ \\
\hline 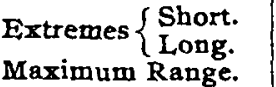 & $\begin{array}{r}.8 I \\
1.42\end{array}$ & $\begin{array}{r}.78 \\
1.80 \\
1.02\end{array}$ & $\begin{array}{l}1.61 \\
2.25\end{array}$ & $\begin{array}{r}1.04 \\
3.80 \\
2.76\end{array}$ & $\begin{array}{r}.75 \\
2.95\end{array}$ & $\int_{25}^{.70}$ \\
\hline
\end{tabular}

EXPERIMENT III.

Having been successful in the previous enumerated trials and others, we determined to further restrict any advantage which the experimenters might have over the subject. Two men, Mr. S. and Mr. O., both of whom had knowledge as to the nature of the association reaction method, were selected, and they were given the following options: (I) both might perform the series of acts according to instructions; (2) either one could 
perform them; (3) neither need necessarily perform them; (4) after having chosen what they would do they were allowed to conceal, or not to conceal, their individual relation to the experiment.

In a drawer of a table in the psychological laboratory, the following things were placed; three bottles of ink (carmine, green and violet), two pieces of glass (red and blue), a onepound iron weight, a handkerchief scented with asafœtida, a copy of The Psychology of Advertising, by Walter D. Scott, and The Native Tribes of Central Australia, by Spencer and Gillen.

The written instructions were as follows:

"I. Take the book, The Psychology of Advertising. Who is the author? Turn to page 44. Read the advertisement on that page carefully."

“2. There are three bottles of ink in the drawer. Notice carefully the color. Are the bottles full or empty?"

"3. Take the book by Spencer and Gillen, The Native Tribes of Central Australia." This is a large book. How many pages has it? Turn to page 33 and notice the old man. Also turn to page 47 .

Is not she a winsome lass? It is too bad that she has lost one tooth!"

Mr. S. was first examined and in order to increase the probability that our conclusions were correct the list of words was given a second time. Mr. O. was then examined in the same way. The results are indicated in Table V.

A comparison of Mr. O.'s figures in Table V. with those of Table I. shows that, while his figures are somewhat higher than those of some other normal subjects, yet the difference between the means in Experiment III. is much less than in the first experiment, in which he tried to conceal. Moreover, the mean variation both for the irrelevant and significant words is in general much lower than in the previous experiment. It will also be seen by a comparison of the quantitative results of these experiments that his maximum range is much higher in the first than in the last. The variability, however, of his reactions was not a sufficient basis for concluding that he was trying to con- 
Table V.

RESULIS OF EXPERIMRNT III.

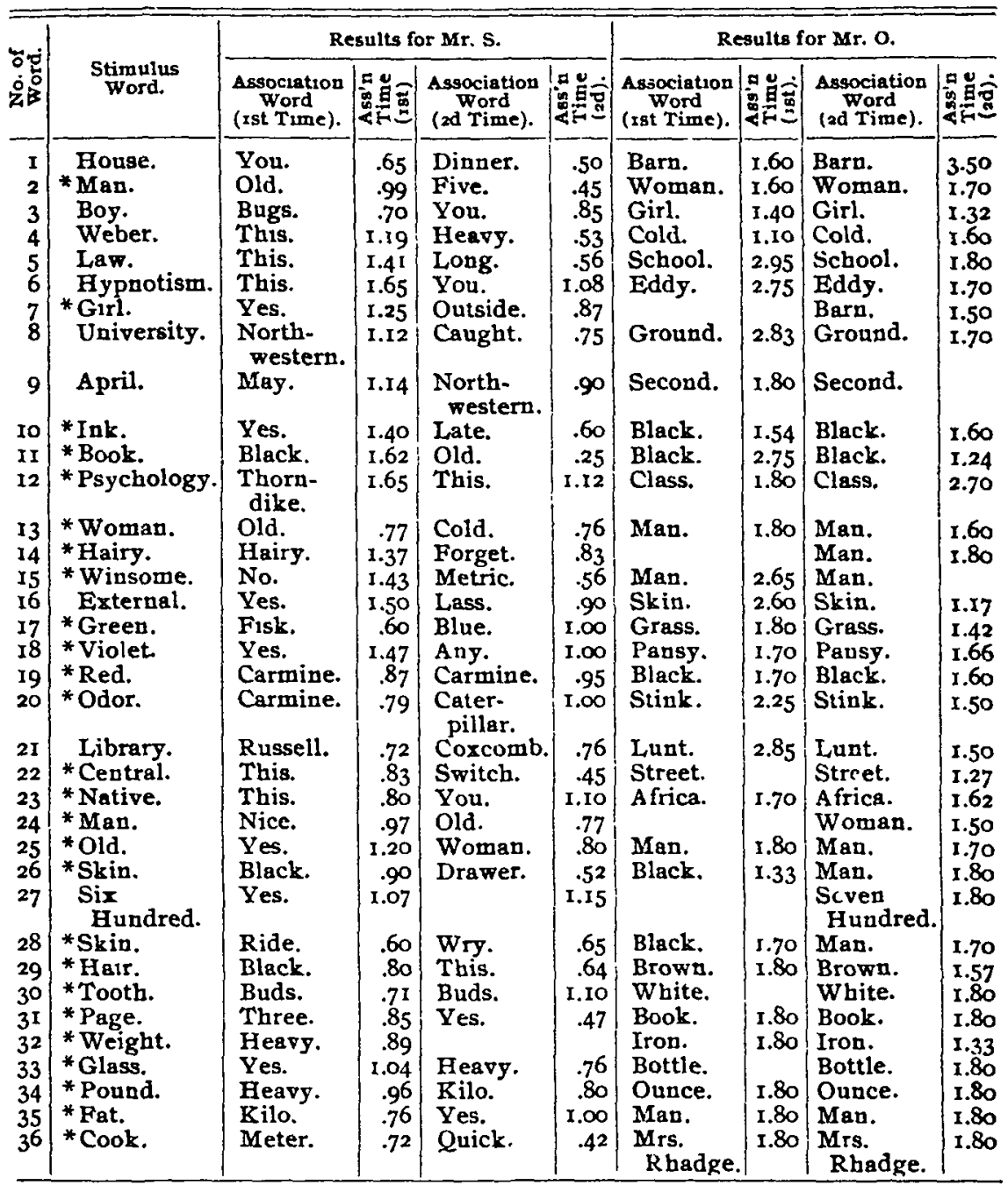

ceal. It will be remembered that there was a handkerchief scented with asafœdita in the drawer. When the word odor was given, $O$. gave the association stink. Again, when the stimulus word weight was given, he answered, iron. This, perhaps, because of the iron weight in the drawer. And when the word hairy was given the reply was man. This would ap- 
pear to be on account of the picture of a hairy man on page 33 of the book, The Native Tribes of Central Australia.

In the case of $\mathrm{Mr}$. S. it is at once apparent that for some reason he repeated words in giving associations which were manifestly not prompted by the stimulus word. This is shown by the short reaction time. The word red called up the word carmine, which was the name on one of the bottles of ink. When winsome was given he gave the word metric in .56 of a

TABLE VI.

QUANTITATIVI RESUITS OF EXPERIMENT III.

\begin{tabular}{|c|c|c|c|c|c|c|c|c|}
\hline & \multicolumn{4}{|c|}{ Results Mr. S. } & \multicolumn{4}{|c|}{ Results Mr. O } \\
\hline & 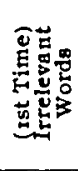 & 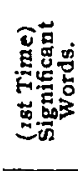 & 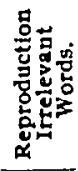 & 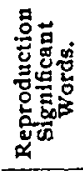 & 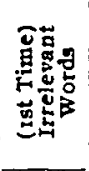 & 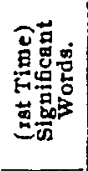 & 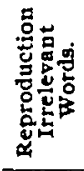 & 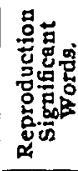 \\
\hline $\begin{array}{l}\text { Mean. } \\
\text { Mean Variation. } \\
\text { Difference in Means. }\end{array}$ & $\begin{array}{r}1.01 \\
.26 \\
+\end{array}$ & $\begin{array}{l}1 . I I \\
.20 \\
.10\end{array}$ & $\begin{array}{r}.75 \\
.26 \\
+\end{array}$ & $\begin{array}{l}.76 \\
.15 \\
\text { or }\end{array}$ & $\begin{array}{r}1.84 \\
.22 \\
+\end{array}$ & $\begin{array}{r}2.21 \\
.65\end{array}$ & $\begin{array}{r}1.66 \\
.18 \\
+\end{array}$ & $\begin{array}{r}1.7^{8} \\
.3^{8}\end{array}$ \\
\hline $\begin{array}{l}\text { Extremes }\left\{\begin{array}{l}\text { Long. } \\
\text { Short. }\end{array}\right. \\
\text { Maximum Range. }\end{array}$ & $\begin{array}{r}1.65 \\
.65 \\
I\end{array}$ & $\begin{array}{r}1.65 \\
.60 \\
.05\end{array}$ & $\begin{array}{r}1.08 \\
.50 \\
.\end{array}$ & $\begin{array}{r}1.12 \\
.25 \\
.7\end{array}$ & $\begin{array}{l}2.95 \\
1.10\end{array}$ & $\begin{array}{r}2.75 \\
\text { I. } 33\end{array}$ & $\begin{array}{l}3.50 \\
1.17 \\
2\end{array}$ & $\begin{array}{l}2.70 \\
1.24 \\
33\end{array}$ \\
\hline
\end{tabular}

second. This word he evidently had in mind as his next association word. Winsome was followed by the stimulus word external, the association given for this being lass, we had reason to believe that this was the actual association called up by the word winsome. By turning to the written directions the phrase, ' winsome lass' will be found. An examination of the quantitative results of the experiment shows that $\mathrm{Mr}$. S. had association words in mind before the stimulus word was given. This has greatly reduced the average time, both for the irrelevant and the significant words. The difference in the association time of the irrelevant and the significant words of $\mathrm{Mr}$. O. indicates the emotional tendency of a significant stimulus word, whether or not the subject tried to alter his first associations.

Our judgment on this last experiment was (I) that both $\mathrm{Mr}$. $O$. and Mr. S. had been in the room and had performed the series of acts, (2) that Mr. O. did not try to conceal, (3) that Mr. S. made an attempt to conceal. 
Our conclusions regarding the general feasibility of the association reaction method in mental diagnosis are as follows:

I. Accurate judgment is reasonably certain, in event the situation is so controlled that the diagnosis take the simple form of determining between two possible alternatives, the exact motive of which is definitely known by the experimenter; our results in this regard have been in substantial agreement with those given by Messrs. Yerkes and Berry. ${ }^{1}$

II. In such cases it is probable that the diagnosis will be so simple that a third party who has observed the experiment will be in a position to draw right conclusions.

III. Knowledge of the association reaction method on the part of the subject, though he attempts to utilize it in concealing his relation to the experiment, does not make a correct diagnosis impossible.

IV. The difficulty of accurate diagnosis increases in proportion as the advantage which the experimenter has over the subject is gradually restricted, and the number of possible diagnoses increased. We see no reason why the situation might not conceivably be so complicated that accurate diagnosis would ipso facto be impossible.

'Cf. The American Journal of Psychology, January, I909, p. 226. 